\title{
The historical origins of aridity and vegetation degradation in south-eastern Spain
}

José S. Carrióna * Santiago Fernándeza, Gonzalo Jiménez-Morenob, Séverine Fauquettec, Graciela Gil-Romerad, Penélope González-Sampérize, Clive Finlayson ${ }^{\dagger}$

a Departamento de Biología Vegetal, Facultad de Biología, Universidad de Murcia, 30100 Murcia, Spain

b Departamento de Estratigrafía y Paleontología, Facultad de Ciencias, Universidad de Granada, Avenida Fuente Nueva S/N, 18002 Granada, Spain

c Université de Montpellier 2, CNRS, Institut des Sciences de I'Evolution, CC 061, Université Montpellier II, Place Eugène Bataillon, 34095 Montpellier cedex 5, France

d Institute of Geography and Earth Sciences, University of Wales, SY23 3DB Aberystwyth, United Kingdom

e Instituto Pirenaico de Ecología-CSIC, Avenida Montañana 1005, 50059 Zaragoza, Spain

t The Gibraltar Museum, 18-20 Bomb House Lane, P.O.Box 939, Gibraltar

*Corresponding author: J.S. Carrión: carrion@um.es, Phone and Fax: (34) 968364995

\begin{abstract}
The complex relationships within modern landscapes cannot be understood without the benefit of retrospective studies. We review palaeoenvironmental data for southeastern Spain, a landscape vulnerable to desertification and with antiquity of human pressure on the landscape. A xerophytic component is discernible in the pollen diagrams of the southeastern peninsula ever since the Middle Miocene. During glacial stages of the Pleistocene, mountain grasslands and lowland steppes expanded, but tree vegetation, although episodically contracted, was ever present across the region, explaining part of the modern plant-species diversity. The magnitude of human impacts on vegetation during the Holocene has been highly variable, starting earlier (e.g. after c. $5000 \mathrm{cal}$ yr BP) in low-elevation areas and river basins. Forest degradation of the mountains started rather late during the Argaric period, and reached its maximum during the Roman occupation. Over the last millennia, natural and/or human-set fires, combined with overgrazing, probably have pushed forests over a threshold leading to the spread of grassland,
\end{abstract}


thorny scrub, junipers, and nitrophilous communities. The high degree of xerophytization observed today in southeastern Spain results from the long-term determinism of the mid-late Holocene climate aridification, and the contingency of historical factors like fire events and changes in prehistoric local economies involving resource exhaustion.

\section{Key words}

Palaeoecology, historical biogeography, Spain, Tertiary, Quaternary, Holocene

\section{Introduction}

This paper deals with the ecological history of a semi-desert region, the Murcian-Almerian bioprovince, extending over $13,000 \mathrm{~km}^{2}$ in the southeast of the lberian Peninsula (Peinado et al., 1992) (Fig.1). We review available evidence of past vegetation and climate-human-vegetation interactions in the study area with the goal of establishing a temporal framework incorporating the vegetation patterns and the natural processes observed today in an area that has witnessed one of the highest rates of long-term land degradation within the European continent (Puigdefábregas and Mendizábal, 1998). Specific issues to be addressed relate to (i) whether the arid belt with xerothermic Mediterranean, and Saharo-Irano-Turanian elements in the Mediterranean coast of southeastern Iberia is a recent feature or originates during or prior to the Quaternary, (ii) whether the region served as glacial refugium for woody species during the Pleistocene, (iii) whether this generally treeless region was forested any time during the Holocene, and, if so, which arboreal species were involved, (iv) which factor(s) gave rise to the high degree of xerophytization observed in the region today, and (v) whether the palaeo-record of biotic changes, fire occurrence, and anthropogenic disturbance can shed light on the characteristics of modern vegetation. This last issue includes the consideration of causal links with prehistoric patterns of human settlement. 


\section{Present-day climate and vegetation}

Although essentially Mediterranean, with summer drought and average annual temperatures of $16-17^{\circ} \mathrm{C}$ in the lowlands, the climate of the Murcian-Almerian bioprovince is characterised by greater aridity than other Mediterranean areas. Extreme summer temperatures are common, with daily maxima of up to $46^{\circ} \mathrm{C}$. The region is bounded by the Mediterranean Sea and surrounded by mountain ranges acting as a natural barrier to precipitation (IGME, 1999) (Fig. 1). Yearly rainfall ranges from 250 to $330 \mathrm{~mm}$, though in mountainous areas it may exceed $400 \mathrm{~mm}$ and in some coastal areas it falls below $190 \mathrm{~mm}$ (Lázaro et al., 2001). Precipitation is irregular and often causes devastating floods of great erosive power, and evapotranspiration is greater than anywhere else in the Iberian Peninsula (Cantón et al., 2001).

Interestingly, while being one of the most arid regions on the European continent, it is among the richest floristically, perhaps due to the region's extensive bioclimatic gradients and geological diversity (Mota et al., 2004). More than half of the c. 7500 vascular plants found in Iberia (Devesa and Ortega, 2004) occur within the limited territory of this province, a majority of which are Mediterranean species (65\%), including Iberian, Murcian-Almerian, Ibero-North African and Ibero-Irano-Turanian endemics (Mota et al., 2003). In the most arid environments, namely coastal mountains and littoral depressions, sclerophyllous brushwoods prevail, dominated by one or more of the following species: Maytenus senegalensis subsp. europaea, Periploca angustifolia, Withania frutescens, Ziziphus lotus, Calicotome intermedia, Launaea arborescens, and several species of Genista. Other abundant species include Lycium intricatum, Rhamnus oleoides, Pistacia lentiscus, Olea europaea var. sylvestris, Stipa tenacissima, Ephedra fragilis, as well as a diversity of Cistaceae, Lamiaceae, and Asteraceae species. Open forests with Pinus halepensis and Quercus rotundifolia, and Quercus coccifera scrub occur in the more continental depressions and less dry conditions of the mountainous hinterland. Saline depressions, as well as intermittent 
watercourses, are colonised by Artemisia, Chenopodiaceae, Nerium oleander, Tamarix, Limonium, and Poaceae species.

\section{Aridity was already present in the late Tertiary}

Little is known about the Tertiary (65-1.8 Ma) evolution of Iberian floras. Available data suggest that aridity is a feature of the southeastern peninsula ever since the middle Miocene, about 16 million years ago. It is also possible that Mediterranean-type climates had appeared intermittently during the Miocene (23-5.3 Ma), as Tzedakis (2007) has recently suggested. Pollen spectra in

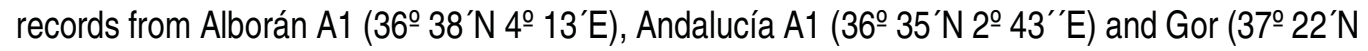
$2^{\circ} 59^{\prime} \mathrm{W}$ ) (Fig. 1), include minor subdesertic elements since the Langhian (16-13.6 Ma) such as Nitraria, Neurada, Prosopis, Lygeum, Ephedra, Caesalpiniaceae, Acacia and Calligonum, while non-arboreal elements (Poaceae, Chenopodiaceae-Amaranthaceae, Plumbaginaceae, Caryophyllaceae) prevail in the pollen spectra (Jiménez-Moreno, 2005) (Fig. 2). These elements are but a part of a complex assemblage involving tropical and subtropical components (Taxodium-Glyptostrobus, Bombax, Engelhardia, Sapotaceae, Myrica, Buxus bahamensis, Croton, Alcornea, Mussaenda), mangrove species (Avicennia), and mesothermic (deciduous Quercus, Carya, and Zelkova ), mid-altitude (Cedrus, Tsuga) and high-altitude (Abies, Picea) trees (Jiménez-Moreno and Suc, 2007). Physiographic heterogeneity must have been important at this time, as the rainfall requirements of these taxa vary greatly. Doubtless, the arid conditions were not widespread in the southeastern peninsula but there must have been sub-desertic areas because the Neurada-Nitraria assemblages are typical of the northern fringes of the Sahara today (Fauquette et al., 2006), and the Middle Miocene (c. 16-11 Ma) pollen sequences from the southeast contain a greater herbaceous component than northeastern records (Jiménez-Moreno and Suc, 2007). 
The pollen sequence of the Andalucía G1 borehole (Fig.1) follows the erosional phase corresponding to the deep Mediterranean salinity crisis (Clauzon et al. 1990), and has been dated from c. 5.32 to $2.4 \mathrm{Ma}$ (Suc et al. 1995). This sequence includes abundant herbs (Poaceae, Asteraceae, Chenopodiaceae-Amaranthaceae, Artemisia), deciduous Quercus, and subdesertic elements such as Lygeum, Nitraria, and Calligonum, indicating dry and hot conditions (Fauquette et al., 1998). These elements are, however, also present in the Tarragona E2 borehole, offshore northeastern Spain (Bessais and Cravatte, 1988) (Fig. 1), suggesting that an arid thermomediterranean belt with Saharo-Irano-Turanian elements continued to occur during the Pliocene along the Mediterranean coast of Iberia from Andalucía to southern Cataluña. Fauquette et al. (1999) quantified climatic conditions for this site through a pollen-derived method based on the mutual climatic range of plant taxa. Apart from the record of two major coolings that took place at 4.5 and 3.5 Ma (Suc and Zagwijn, 1983), annual temperatures remained equivalent to $6^{\circ} \mathrm{C}$ higher than today, and annual precipitation was eventually lower than today (if the Pliocene climate is calculated excluding deciduous Quercus, on the assumption that the species occupied mountainous areas adjacent to the study site (Fauquette et al.,1999)). The Pliocene at Andalucía G1 strongly contrasts with the site of Rio Maior in Portugal where Ericaceae dominates the nonarboreal pollen spectra and the subtropical component (Cathaya, Engelhardia, Sequoia, Myrica, Taxodium...) dominates the arboreal (Diniz, 1984). Using the former method of climatic estimation, their pollen data, and the plant functional types established by Prentice et al. (1992), Fauquette et al. (1999) reconstructed Pliocene biomes between 5.32 and 5 Ma for the West Mediterranean area. Hot desert, semi desert, xerophytic scrub, and warm grass/shrub biomes were reconstructed for southeastern Spain (Fig. 3).

\section{Glacial refugium for tree taxa}


Early to Mid-Pleistocene palaeobotanical records of the study region are lacking. If we take into account the biogeochemistry and ecomorphology of the large mammal assemblage, we can infer early Pleistocene landscapes characterised by the presence of shallow lakes with swampy marginal zones and extensive areas of savanna with tall grass and shrubs (Palmqvist et al., 2003). For the better documented Upper Pleistocene, the region can be broadly characterized by a diversity of landscapes including mountain grasslands and lowland steppes, Pinus woods at mid-altitudes, and the occurrence of a number of woody plants in the present-day meso and thermomediterranean belts along coastal shelfs and intramontane valleys (Carrión et al., 2008). Glacial stages are characterized by the expansion of desert-like communities of Poaceae, Artemisia, Chenopodiaceae, Asteraceae, Ephedra, and Lamiaceae, among others (Finlayson and Carrión, 2007). However, mesothermophilous taxa occur along the coastal shelfs such as in the

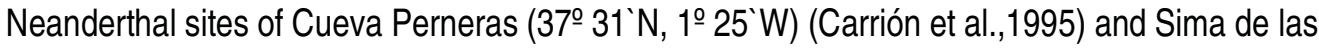
Palomas (37ํㅜㄱ' N, 0ํ5’ W) (Carrión et al., 2003b) (Fig. 1). These sites have provided abundant pollen of Pinus, Quercus and Oleaceae, and continuous or frequent occurrence of broad-leaved trees (Fraxinus, Alnus, Corylus, Juglans, Ulmus, Salix) and thermophytes (Myrtus, Erica arborea, Pistacia, Buxus, Periploca, Maytenus, Osyris, Withania, Lycium, Calicotome, Ephedra fragilis). At San Rafael marshland there is continuous occurrence of evergreen and deciduous Quercus and Olea from c. 16000 to 10000 BP (Pantaleón-Cano et al., 2003). Anthracological studies on charcoal fragments, Pinus cone remains, and Pinus kernel shells in Nerja Cave, Málaga, document the occurrence of three species of Pinus between c. 24000 and 17500 yr BP: Pinus pinea, Pinus nigra and Pinus halepensis (Badal, 1998). Charcoal of Pinus, Quercus, Juniperus, Cistus, Rhamnus-Phillyrea, Prunus, and Sorbus-Crataegus have been found (Badal, 1998).

In general, the inland areas of south-eastern Spain fail to show continuous presence of mesothermophilous taxa during the last glacial stage. The pollen sequences from Beneito Cave 


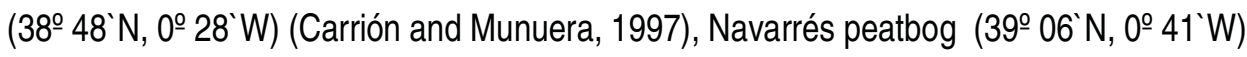

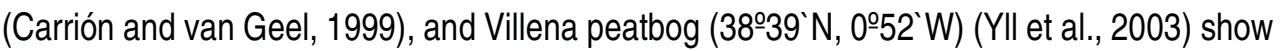
episodic occurrences of Quercus and other woody taxa during OIS3, like Padul peatbog (37ㅇN, $3^{\circ}$

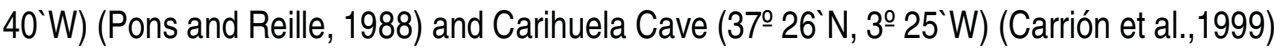
during OIS4, OIS3 and OIS2. Lateglacial (after c. 15000 years BP) Quercus invasions (Pons and Reille,1988; Fernández et al., 2007) suggest the proximity of refugia of evergreen and deciduous Quercus.

Refugia for woody taxa developed not only along the thermomediterranean belt in the coast, but also along intramontane valleys where sufficient precipitation may have provided enough moisture to support trees within a generally arid environment. Here, the lacustrine pollen site of Siles (Carrión, 2002) (38을 $\left.24^{`} \mathrm{~N}, 2^{\circ} 30^{\circ} \mathrm{W}\right)$, dating from upper pleniglacial times (c. $17030 \mathrm{yr}$ BP), includes Pinus pinaster, deciduous Quercus, evergreen Quercus, Ericaceae, Corylus, Betula, and Fraxinus, in pollen percentages always above $2 \%$, and also frequently with Acer, Taxus, Arbutus, Buxus, Salix, Ulmus, Phillyrea, Pistacia, and Olea.

\section{Mid to late Holocene xerophytization}

The Holocene is a time of great environmental variability in Mediterranean Spain. Several pollen sequences show an early-Holocene dominance by Quercus (Pons \& Reille, 1988; GonzálezSampériz, 1998; Fernández et al., 2007), but in others Pinus continues to be dominant until the mid Holocene (Carrión \& van Geel, 1999; Carrión et al. 2001b) or long thereafter (Stevenson, 2000; Franco et al., 2005). Overall, the period from c. $7500-5000$ cal yr BP represents the mesophytic optimum, the xerophytic minimum, the period of lowest fire activity, and locally, a phase of relatively high lake levels (Carrión et al., 2001c, Carrión, 2002). During this period, the mountainous areas were forested with several species of Pinus, Quercus faginea, Q. pyrenaica, Q. ilex, Q. suber, broad-leaf trees (Corylus, Alnus, Betula, Acer, Fraxinus, Ulmus, Juglans, 
Arbutus, Salix, Castanea) and other woody taxa (Juniperus, Taxus, Olea, Phillyrea, Pistacia, Buxus, Prunus, Ephedra fragilis) (Carrión et al., 2007, 2008).

A relevant question is when did the arid southeast attain its present status? In addition, what was the ultimate factor that provided the high degree of xerophytization observed today (Calmel-Avila, 2000)? A comparative analysis of palaeobotanical data from the Murcian-Almerian province and surroundings (Fig. 1) sheds light onto these questions. The pollen sequences of

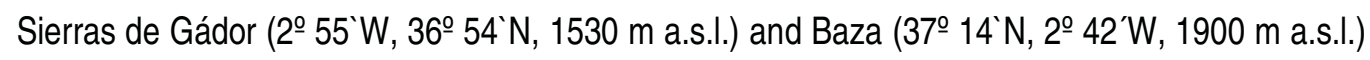
are particularly useful in this respect.

Holocene ecological change in Sierra de Gádor has been constant, and at times, rapid (Carrión et al., 2003a). After c. 3940 cal yr BP, frequent alternation of dominance of Pinus and evergreen Quercus at the expense of deciduous Quercus, is observed. This change is preceded by increases of microcharcoal particles at c. $4200 \mathrm{cal}$ yr BP, suggesting enhanced fire (Fig. 4). Fire events along the Gádor sequence are correlative of xerophyte pollen (Lygeum, Chenopodiaceae, Artemisia, Lamiaceae, Ephedra fragilis), but the change towards sclerophyllous vegetation is also contemporaneous with the Argaric settlement, which, according palaeoanthracological analyses (Rodríguez-Ariza, 1992), would have intensified pastoralism, forest destruction and matorralization. A Poaceae increase after c. 1760 cal yr BP is preceded by rising percentages of Sordariaceae, Polygonum aviculare, Riccia and Genisteae, indicating heavy grazing in the lake catchment (Carrión et al., 2003a). The first pollen records of Vitis are dated at C. 1600 cal yr BP (Fig. 4). Pastoralism and agriculture are further supported by charcoal and seed remains of Olea, Vitis, and heliophytic taxa in the excavation sites of the slopes (Rodríguez-Ariza, 1995; Buxó, 1997), and archaeological evidence suggests great demographic pressure during Roman times (Cámalich and Martín, 1999). Sierra de Gádor today is a treeless mountain, but one millennium ago, several taxa were found that are now extinct in the Sierra, such as Taxus baccata, Corylus avellana, Betula celtiberica, Alnus glutinosa, and Myrtus communis (Carrión et 
al., 2003a). Others, like Arbutus unedo, Buxus sempervirens, B. balearica, and Acer granatense, have become extremely rare. In addition, historical records and toponimic information suggest there was extensive brush and Pinus and Quercus forest cover in several mountain systems of Almería only three centuries ago (García-Latorre and García-Latorre, 1996). These most recent changes could have resulted from impact of lead extraction, beginning in 1822 (Grove and Rackham, 2001). The current treeless condition of Sierra de Gádor is, therefore, a relatively recent phenomenon. Under the long-term influence of increased dryness and burning, opening of the landscape may have started patchily after c. 3940 cal yr BP, but the definitive loss of forest is a human-induced case.

Like Gádor, the history of the vegetation in Sierra de Baza appears clearly influenced by changes in local economy, with emphasis on the highly-populated Argaric period, in a context of increased dryness over the last 5000 years (Carrión et al., 2007). The replacement of mesophytic by more xeric Mediterranean vegetation around $3800 \mathrm{cal}$ yr BP is preceded by greater fire activity at c. 4100 cal yr BP. Grassland scrub and thorny matorral spread after c. 2560 cal yr BP (Fig. 4). Sierra de Baza is today partially forested due to recent afforestations, but deforestation became strong over the last two millennia, when anthropogenic disturbance (agriculture, mining, pastoralism) reached its maximum.

Anthropogenic landscapes have their origins later in more continental territories, like the Segura Mountains (Fig. 1). Yet, spatial complexity prevailed. Plantago and other indicators of agriculture and arboriculture, and indicators of forest degradation, occur first in the pollen record of the mesomediterranean Villaverde (c. 2200-1600 cal yr BP) (Fig. 4), then in Siles (c. $1400 \mathrm{cal}$ yr BP) and El Sabinar (c. 1353 cal yr BP), and finally in the high-elevation Cañada de la Cruz (c. 670 cal yr BP) (Carrión, 2002b) (Fig. 1). Archaeological data from the Neolithic to the Bronze Age suggest that settlement was sparse in these mountains, and that agriculture was not important before Roman times (Jordán, 1992). Documentary evidence suggests that only in the last 
centuries has population growth and the improvement of agricultural technologies caused transformation of forests into croplands at low- and mid-altitudes, although many areas were left uncultivated or reverted to grazing until the present-day, and much of the forested territory was managed exclusively for timber (Sánchez-Gómez et al., 1995).

Important forest losses are detected earlier in thermomediterranean areas than in the mountains and most continental territories. The San Rafael marshland pollen record, in the littoral $\left(36^{\circ} 46^{\prime} \mathrm{N}, 2^{\circ} 36^{\prime} \mathrm{W}\right.$ ), shows the development of shrublands (with expansion of communities of Artemisia and Chenopodiaceae) since the mid Holocene c. 5000 cal BP (Pantaleón-Cano et al., 2003) (Fig. 4). A similar sequence occurs at Roquetas (Pantaleón-Cano et al., 2003), Gata (Burjachs et al., 2000, Jalut et al., 2000), Antas (Pantaleón-Cano et al., 2003), and Caldereros (Fuentes et al., 2006) (Fig. 1). Geomorphological studies confirm a gradual erosive down cutting of many river catchments in the south-east from the Chalcolithic (Calmel-Avila, 2000). Anthracological studies also suggest that the anthropic impact in the thermomediterranean began earlier, since the Neolithic. This lead to the progressive expansion of garrigues, depending on the locality, to the detriment of Pinus and arboreal Quercus (Badal et al., 1994, Rodríguez-Ariza, 2000). During and after the Chalcolithic, the well-developed riparian vegetation became progressively denuded in the lowland river valleys and their immediate surroundings (RodríguezAriza, 1992).

Modern vegetation in southeastern Spain cannot be adequately understood in the absence of the palaeorecord. It is worth emphasizing that Pinus forests are natural in the region while evergreen Quercus-dominated formations are not systematically the pre-anthropic stage of vegetation (Carrión et al., 2004). Mixed conifer-Quercus forests including deciduous Quercus are a common feature in the middle Holocene (Fig. 4). Several species such as Corylus avellana, Betula celtiberica, Acer granatense, Taxus baccata, and Arbutus unedo are relics of the midHolocene mesic forests (Carrión et al., 2003a). The pollen sequences are also pertinent to 
discern the ecological affinities of several species such as Maytenus europaeus, Chamaerops humilis, Myrtus communis, Asparagus, Phillyrea (cf. P. media), and Buxus sempervirens/balearica, which behaved as mesophytes by reaching a maximum during the mid Holocene (Carrión et al., 2003a). These taxa have declined since c. 4000 yr BP, and their variation does not correlate with that of the xerothermic scrub of Ziziphus, Withania, Periploca, and Calicotome, which have been phytosociologically related with (Peinado et al., 1992).

\section{Conclusions}

Aridity is a feature of southeastern Spain ever since the Middle Miocene, 16 million years ago, which is characterized by complex palynological assemblages including a subdesertic component with Nitraria, Neurada, Prosopis, Lygeum, Ephedra, Caesalpiniaceae, Acacia and Calligonum. For the Pliocene (5.3-1.8 Ma), pollen records also reflect the occurrence of episodes with abundant herbs (Poaceae, Asteraceae, Chenopodiaceae-Amaranthaceae, Artemisia), and subdesert elements such as Lygeum, Nitraria, and Calligonum which indicate dry and hot conditions. During the Pleistocene (1.8-0.1 Ma), southeastern Iberia can be characterized by a diversity of landscapes including mountain grasslands and lowland steppes, Pinus woods in midaltitudes and a number of woody plants in the present-day meso and thermomediterranean belts along coastal shelfs and intramontane valleys. Forest cover was less extensive but ever present across the region during glacial stages, with the occurrence of Pinus, Quercus, Juniperus, Abies, Corylus, Betula, Alnus, Ulmus, Salix, Castanea, Fraxinus, Juglans, Acer, Sorbus, Taxus, Olea, Pistacia, Phillyrea, Arbutus, and Myrtus, among others.

Complicating the effects of climate on vegetation during the Holocene is the impact of humans, which has been highly variable over southeastern Spain, starting earlier in low-elevation areas and river basins. Forest degradation of the mountains started late during the Argaric period (4300-3600 cal yr BP), and reached its maximum during the Roman occupation, c. $2000 \mathrm{cal}$ yr 
BP. Over the last two millennia, natural and/or human-set fires, combined with overgrazing, would have pushed mountain forests over a threshold leading to the spread of grassland, thorny scrub, junipers, and nitrophilous communities. Specifically-orientated projects could be directed towards the investigation of whether ancient forests would be able to recover if anthropogenic pressures ceased, but the picture would remain speculative because demographic pressure is becoming greater over the last years. It can be concluded that the high degree of xerophytization observed today in southeastern Spain is not an unicausal process, but rather it is spatially heterogeneous, and resulting from a combination of anthropogenic disturbance, and resource exhaust under enhanced aridity.

\section{Acknowledgements}

This research has been funded by the projects CGL-2006-2956-BOS (Ministerio de Educación y Ciencia, Madrid) and Paleodiversitas Network (Fundación Séneca, Murcia). This paper is an ISEM contribution $n^{\circ} 2008^{* \star *}$. This paper has benefited by changes suggested by R. Scott Anderson, Northern Arizona University, and an anonymous referee on an earlier draft.

\section{References}

Badal, E., 1998. Interés económico del pino piñonero para los habitantes de la Cueva de Nerja. In: Sanchidrián, J.L., Simón, M.D. (Eds.), Las culturas del Pleistoceno Superior en Andalucía. Patronato de la Cueva de Nerja, Málaga, pp. 287-300.

Badal, E., Bernabeu, J., Vernet, J.L., 1994. Vegetation changes and human action from the Neolithic to the Bronze Age (7000-4000 B.P.) in Alicante, Spain, based on charcoal analysis. Vegetation History and Archaeobotany 3, 155-166. 
Bessais, E., Cravatte, J., 1988. Les écosystèmes végétaux pliocènes de Catalogne méridionale. Variations latitudinales dans le domaine nord-ouest méditerranéen. Geobios 21, 49-63.

Burjachs, F., Giralt, S., Roca J.R., Seret, G., Julià, R., 1997. Palinología holocénica y desertización en el Mediterráneo occidental. In: Ibáñez J.J., Valero, B.L., Machado, C. (Eds.), El paisaje mediterráneo a través del espacio y del tiempo. Implicaciones en la desertificación, Geoforma Editores, Logroño, pp. 379-394.

Burjachs, F., Febrero, A., Rodríguez-Ariza, M.O., Buxó, R., Araus, J.L., Julià, R. 2000. Holocene pollen sequences and carbon isotope discrimination of plant remains in Spain: evidence of a progressive increase in aridity. In: Balabanis, P., Peter, D., Ghazi, A., Tsogas, M. (Eds.), Mediterranean desertification. Research Results and policy implications. Directorate General Research, Brussels.

Buxó, R., 1997. Arqueología de las plantas. Crítica, Barcelona.

Calmel-Avila, M., 2000. Procesos hídricos holocenos en el Bajo Guadalentín (Murcia, SE España). Cuaternario y Geomorfología 14, 65-78.

Cámalich, M.D., Martín, D., 1999. El territorio almeriense desde los inicios de la producción hasta fines de la antigüedad. Un modelo: la Depresión de Vera y Cuenca del Río Almanzora. Arqueología, Monografías, Junta de Andalucía, Sevilla.

Cantón, Y., Domingo, F., Solé Benet, A., Puigdefábregas, J., 2001. Hydrological an erosion response of a badlands system in semiarid SE Spain. Journal of Hydrology 252, 65-84. 
Carrión, J.S., 2002a. A taphonomic study of modern pollen assemblages from dung and surface sediments in arid environments of Spain. Review of Palaeobotany and Palynology 120, 217-232.

Carrión, J.S., 2002b. Patterns and processes of Late Quaternary environmental change in a montane region of southwestern Europe. Quaternary Science Reviews 21, 2047-2066.

Carrión, J.S., Andrade, A., Bennett, K.D., Navarro, C., Munuera, M., 2001b. Crossing forest thresholds: inertia and collapse in a Holocene sequence from south-central Spain. The Holocene $11,635-653$.

Carrión, J.S., Dupré, M., Fumanal, M.P., Montes, R., 1995. A palaeoenvironmental study in semiarid southeastern Spain: the palynological and sedimentological sequence at Perneras Cave (Lorca, Murcia). Journal of Archaeological Science 22, 355-367.

Carrión, J.S., Finlayson, C., Finlayson, G., Allué, E., López-Sáez, J.A., López-García, P., Fernández-Jiménez, S., Gil, G., Fuentes, N., González-Sampériz, P. 2008. A coastal reservoir of biodiversity for Upper Pleistocene human populations. Palaeoecological investigations in Gorham's Cave (Gibraltar) in the context of the Iberian Peninsula. Quaternary Science Reviews (in press).

Carrión, J.S., Fuentes, N., González-Sampériz, P., Sánchez-Quirante, L., Finlayson, C., Fernández, S., Andrade, A. 2007. Holocene environmental change in a montane region of southern Europe with a long history of human settlement. Quaternary Science Reviews 26, 14551475. 
Carrión, J.S., Munuera, M., 1997. Upper Pleistocene palaeoenvironmental change in eastern Spain: new pollen analytical data from Cova Beneito (Alicante). Palaeogeography, Palaeoclimatology, Palaeoecology 128, 287-299.

Carrión, J.S., Munuera, M., Dupré, M., Andrade, A., 2001c. Abrupt vegetation changes in the Segura mountains of southern Spain throughout the Holocene. Journal of Ecology 89, 783-797.

Carrión, J.S., Munuera, M., Navarro, C., Burjachs, F., Dupré, M., Walker, M.J., 1999. The palaeoecological potential of pollen records in caves: the case of Mediterranean Spain. Quaternary Science Reviews 18, 1061-1073.

Carrión, J.S., Sánchez-Gómez, P., Mota, J.F., Yll, E.I., Chaín, C., 2003a. Fire and grazing are contingent on the Holocene vegetation dynamics of Sierra de Gádor, southern Spain. The Holocene 13, 839-849.

Carrión, J.S., van Geel, B., 1999. Fine-resolution Upper Weichselian and Holocene palynological record from Navarrés (Valencia, Spain) and a discussion about factors of Mediterranean forest succession. Review of Palaeobotany and Palynology 106, 209-236.

Carrión, J.S., Willis, K.J., Sánchez Gómez, P., 2004. Holocene forest history of the eastern plateaux in the Segura Mountains (Murcia, southeastern Spain). Review of Palaeobotany and Palynology 132, 219-236. 
Carrión, J., Yll, E., Walker, M., Legaz, A., Chaíns, C., López, A., 2003b. Glacial refugia of temperate, Mediterranean and Ibero-North African flora in south-eastern Spain: new evidence from cave pollen at two Neandertal man sites. Global Ecology and Biogeography 12, 119-129.

Clauzon, G., Suc, J.P., Aguilar, J.P., Ambert, P., Capetta, H., Cravatte, J., Drivaliari, A., Domènech, R., Dubar, M., Leroy, S., Martinell, J., Michaux, J., Roiron, P., Rubino, J.L., Savoye, B., Vernet, J.L., 1990. Pliocene geodynamic and climatic evolutions in the French Mediterranean region. Paleontology and Evolution, Special Memories 2, 131-186.

Devesa, J.A., Ortega, A., 2004. Especies vegetales protegidas en España: plantas vasculares. Naturaleza y Parques Nacionales, Serie Técnica, Ministerio de Medio Ambiente, Madrid.

Fauquette, S., Quézel, P., Guiot, J., Suc, J.P., 1998. Signification bioclimatique de taxons-guides du Pliocène Méditerranéen. Geobios 31, 151-169.

Fauquette, S., Suc, J.P., Bertini, A., Popescu, S.M., Warny, S., Bachiri, N., Pérez Villa, M.J., Chikhi, H., Feddi, N., Subally, D., Clauzon, G., Ferrier, J., 2006. How much did climate force the Messinian salinity crisis ? Quantified climatic conditions from pollen records in the Mediterranean region. Palaeogeography, Palaeoclimatology, Palaeoecology 238, 281-301.

Fauquette, S., Suc, J.P., Guiot, J., Diniz, F., Feddi, N., Zheng, Z., Bessais, E., Drivaliari, A., 1999. Climate and biomes in the West Mediterranean area during the Pliocene. Palaeogeography, Palaeoclimatology, Palaeoecology 152, 15-36. 
Fernández, S., Carrión, J.S., Fuentes, N., González-Sampériz, P., Gil, G., García-Martínez, M.S., Vega-Toscano, L.G., Riquelme, J.A., 2007. Palynology of Carihuela Cave, southern Spain: completing the record. Geobios 40, 75-90.

Finlayson, C., Carrión, J. S., 2007. Rapid ecological turnover and its impact on Neanderthal and other human populations. Trends in Ecology and Evolution 22, 213-222.

Franco, F., García-Antón, M., Maldonado, J., Morla, C., Sainz, H., 2005. Ancient pine forest on inland dunes in the Spanish northern Meseta. Quaternary Research 63, 1-14.

Fuentes, N., García Martínez, M., González Sampériz, P., Fernández, S., Carrión, J.S., Ros, M., López Campuzano, M. \& Medina, J., 2005. Degradación ecológica y cambio cultural durante los últimos cuatro mil años en el sureste ibérico semiárido. Anales de Biología 27, 69-84.

García-Latorre, J., García-Latorre, J., 1996. Los bosques ignorados de Almería. Una interpretación histórica y ecológica. In: Sánchez-Picón, A. (Ed.), Historia y medio ambiente en el territorio almeriense, Almería: Servicio de Publicaciones, Universidad de Almería, pp. 99-126.

González-Sampériz, P., 1998. Estudio palinológico de la Cueva de En Pardo (Planes, Alicante). Primeros resultados. Cuaternario y Geomorfología 12, 45-61.

Grove, A.T., Rackham, O., 2001. The nature of Mediterranean Europe. An ecological history. Yale University Press, New Haven and London. 
Harzhauser, M., Piller, W. 2007. Benchmark data of a changing sea. Palaeogeography, Palaeobiogeography and events in the Central Paratethys during the Miocene. Palaeogeography, Palaeoclimatology, Palaeoecology 253, 8-31.

IGME. 1999. Atlas del medio natural de la Región de Murcia. Consejería de Política Territorial y Obras Públicas. Instituto Geológico y Minero, Madrid.

Jalut, G., Esteban, A., Bonnet, L., Gauquelin, T., Fontugne, M., 2000. Holocene climatic changes in the western Mediterranean, from south-east France to south-east Spain. Palaeogeography, Palaeoclimatology, Palaeoecology 160, 255-290.

Jiménez-Moreno, G. 2005. Utilización del análisis polínico para la reconstrucción de la vegetación, clima y estimación de paleoaltitudes a lo largo del arco alpino europeo durante el Mioceno (21-8 Ma). Thesis, University of Granada.

Jiménez-Moreno, G., Suc, J.-P., 2007. Middle Miocene latitudinal climatic gradient in western Europe : evidence from pollen records. Palaeogeography, Palaeoclimatology, Palaeoecology 253: $224-241$.

Jordán, J.F., 1992. Prospección arqueológica en la Comarca de Hellín-Tobarra. Metodología, resultados y bibliografía. Al-Basit 31, 183-227.

Lázaro, R., Rodrigo, F.S., Gutiérrez, L., Domingo, F., Puigdefábregas, J., 2001. Análisis of a 30year rainfall record (1967-1997) in semi-arid Spain for implications on vegetation. Journal of Arid Environments 48, 373-395. 
Mota, J., Cabello, J., Cerrillo, M.I., Rodríguez-Tamayo, M.L., 2004. Los subdesiertos de Almería: naturaleza de cine. Junta de Andalucía, Consejería de Medio Ambiente, Sevilla.

Mota, J., Cueto, M., Merlo, M.E., 2003. Flora amenazada de la provincia de Almería: una perspectiva desde la biología de la conservación. Universidad de Almería, Secretariado de Publicaciones, Almería.

Nogueras, P., Burjachs, F., Gallart, F., Puigdefàbregas, J., 2000. Recent gully erosion in the El Cautivo badlands (Tabernas, SE Spain). Catena 40, 203-215.

Palmqvist, P., Gröcke, D.R., Arribas, A., Fariña, R.A., 2003. Paleoecological reconstruction of a lower Pleistocene large mammal community using biogeochemical $\left(\delta^{13} \mathrm{C}, \delta^{15} \mathrm{~N}, \delta^{18} \mathrm{O}, \mathrm{Sr}: \mathrm{Zn}\right)$ and ecomorphological approaches. Paleobiology 29, 205-229.

Pantaleón-Cano, J., YII, E. I., Pérez-Obiol, R., Roure, J. M., 2003. Palynological evidence for vegetational history in semi-arid areas of the western Mediterranean (Almería, Spain). The Holocene 13, 109-119.

Peinado, M., Alcaraz, F., Martínez-Parras, J.M., 1992. Vegetation of southeastern Spain. J. Cramer, Berlin.

Pons, A., Reille, M., 1988. The Holocene and Upper Pleistocene pollen record from Padul (Granada, Spain): a new study. Palaeogeography, Palaeoclimatology, Palaeoecology 66, 243263. 
Prentice, I.C., Cramer, W., Harrison, S.P., Leemans, R., Monserud, R.A., Solomon, A.M., 1992. A global biome model based on plant physiology and dominance, soil properties and climate. Journal of Biogeography 19, 117-134.

Puigdefábregas, J., Mendizábal, T., 1998. Perspectives on desertification: western Mediterranean. Journal of Arid Environments 39, 209-224.

Rivas-Martínez, S., Asensi, A., Díez-Garretas, B., Molero, J., 1997. Biogeographical synthesis of Andalucía (southern Spain). Journal of Biogeography 24, 915-928.

Rodríguez-Ariza, M.O., 1992. Human plant relationships during the Copper and Bronze Ages in the Baza and Guadix basins (Granada, Spain). Bulletin Societé Botanique de la France 139, 451464.

Rodríguez-Ariza, M.O., 2000. El paisaje vegetal de la Depresión de Vera durante la Prehistoria reciente. Una aproximación desde la antracología. Trabajos de Prehistoria 57, 145-156.

Sánchez-Gómez, P., Carrión, J.S., Jordán, J., Munuera, M., 1995. Aproximación a la historia reciente de la flora y vegetación en las Sierras de Segura Orientales. Albasit 21, 87-111.

Stevenson, A.C., 2000. The Holocene forest history of the Montes Universales, Teruel, Spain. The Holocene 10, 603-610. 
Suc, J.P., Diniz, F., Leroy, S., Poumot, C., Bertini, A., Dupont, L., Clet, M., Bessais, E., Zheng, Z., Fauquette, S., Ferrier, J., 1995. Zanclean (Brunssumian) to early Piacenzian (early-middle Reuverian) climate from $4^{\circ}$ to $54^{\circ}$ north latitude (West Africa, West Europe and West Mediterranean areas). Meded. Rijks Geol. Dienst 52, 43-56.

Suc, J.P., Zagwijn, W.H., 1983. Plio-Pleistocene correlations between the northwestern Mediterranean region and northwestern Europe according to recent biostratigraphic and palaeoclimatic data. Boreas 12, 153-166.

Tzedakis, P.C., 2007. Seven ambiguities in the Mediterranean palaeoenvironmental narrative. Quaternary Science Reviews 26, 2042-2066.

YII, E.I., Carrión, J.S., Pantaleón, J., Dupré, M., La Roca, N., Roure, J.M., Pérez Obiol, R., 2003. Palinología del Cuaternario reciente en la Laguna de Villena (Alicante). Anales de Biología 25, $65-72$.

\section{FIGURE LEGENDS}

Figure 1. Palaeobotanical sites of south-eastern Spain discussed in this paper. Alborán A-1, Andalucía A-1, Andalucía G-1, Tarragona E2 and Gor (Jiménez-Moreno and Suc, 2007), Navarrés (Carrión and van Geel, 1999), Beneito (Carrión and Munuera, 1997), Villaverde (Carrión et al. 2001b), Siles (Carrión 2002a), Sabinar (Carrión et al., 2004), Cañada de la Cruz (Carrión et al., 2001a), Carihuela (Carrión et al., 1999, Fernández et al., 2007), Padul (Pons and Reille, 1988), Nerja (Badal, 1998), Gádor (Carrión et al., 2003a), Baza (Carrión et al., 2007), Las Palomas (Carrión et al., 2003b), Caldereros (Fuentes et al., 2005), Perneras (Carrión et al, 1995), 
Antas, San Rafael, Roquetas de Mar (Pantaleón-Cano et al., 2003), Gata (Jalut et al, 2000). Asterisks refer to sites with evidences of tree pollen during glacial stages of the Pleistocene.

Figure 2. Synthetic pollen diagrams of the Middle Miocene sites Alborán-A1 and Andalucía-A1 in southeastern Spain. Subdesertic elements include Nitraria, Calligonum, Lygeum, Neurada, and Prosopis, among others. Mediterranean xerophytes include Olea, Phillyrea, Ceratonia and Quercus ilex-coccifera. Palaeogeography on palinspastic map of Harzhausser and Piller (2007). Redrawn from Jiménez-Moreno and Suc (2007).

Figure 3. Biomes of the Iberian Peninsula at 5.32-5 Ma using the typology established by Prentice et al. (1992), and climatic estimations. Redrawn from Fauquette et al. (1999).

Figure 4. Comparative chart of vegetational developments during the Holocene in four important pollen sequences from southeastern Spain, from the high-elevation Baza to the littoral San Rafael marshland. A climatically-induced mesophytic optimum is observed during the middle Holocene. Xerophytization starts from c. 5000-4500 cal yr BP, but it is modulated by changes in fire occurrence, and human activities. Deforestated landscapes occur first in the thermomediterranean San Rafael. 


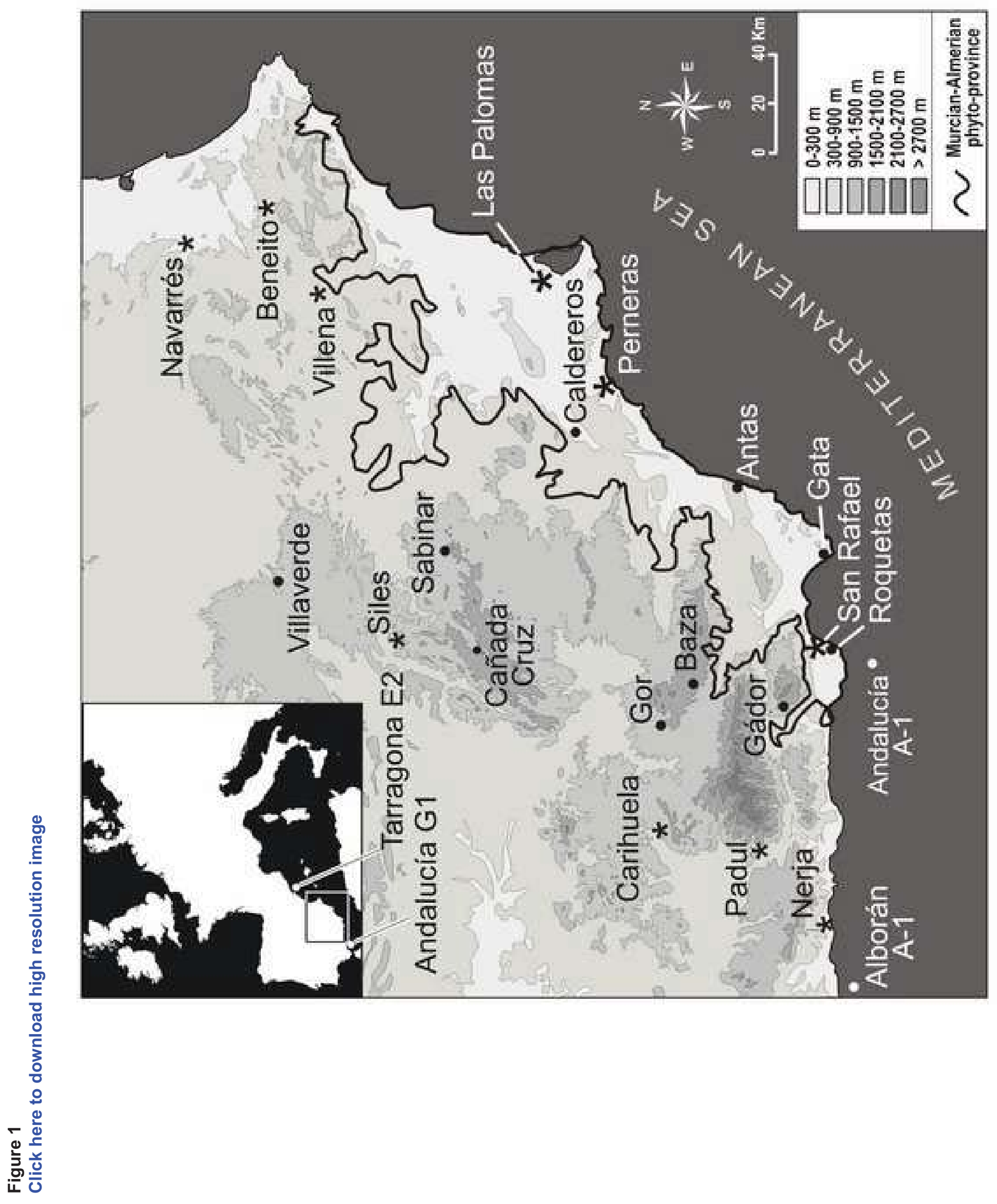



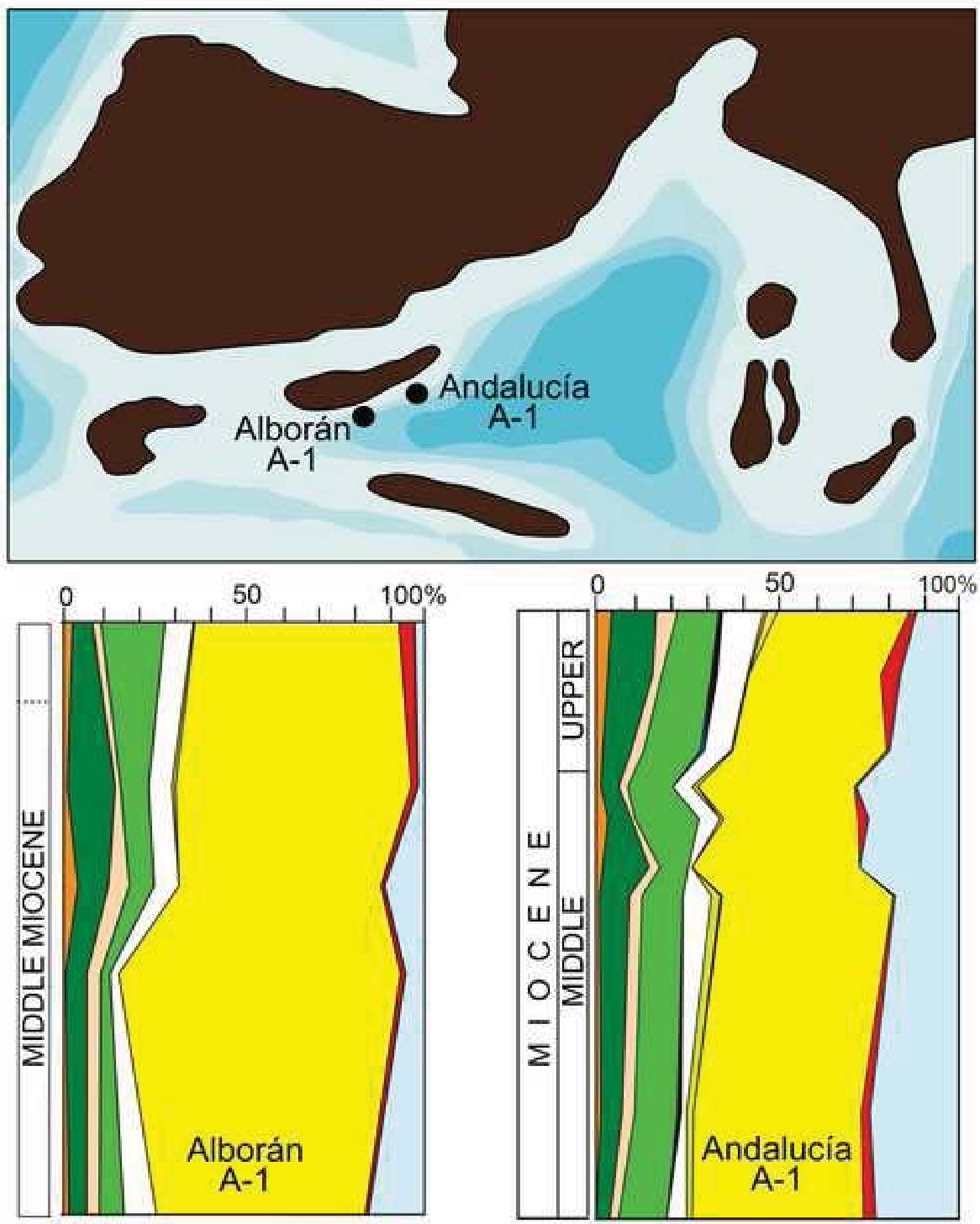

$\square$ Megathermic

$\square$ Mega-mesothermic

$\square$ Middle-altitude conifers

Mediterranean

$\square$ Cathaya

$\square$ Mesothermic

High-altitude conifers

Non-significant

Cupressaceae
Herbs and shrubs

Subdesertic

Halophytes 
Figure 4

Click here to download high resolution image

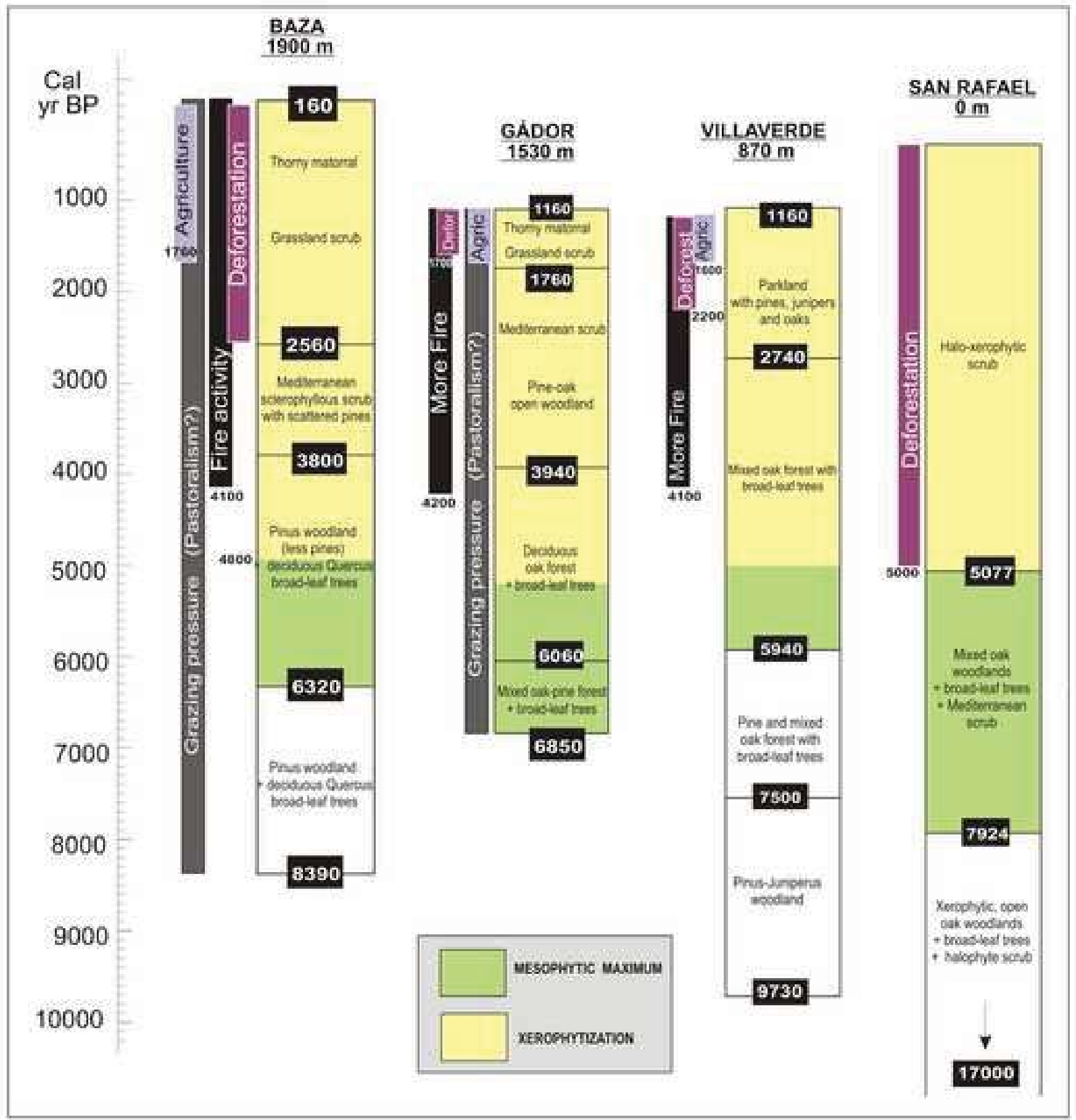

